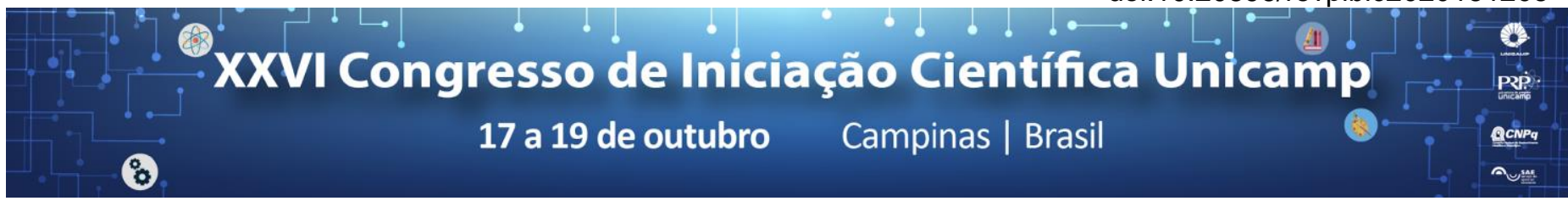

\title{
STRICTO SENSU POST-GRADUATE INTERFACES WITH BASIC EDUCATION.
}

\author{
Leonardo Granero*, Taina R. Gomes*, Tiago Moreira A. Salviano*, Joyce Wassem.
}

\begin{abstract}
This research analyzes the interfaces of Postgraduate Programs (PPG) of the State University of Campinas (UNICAMP) with basic education. The PPGs studied were: Visual Arts, Education, Mathematics and Physical Education. The data collection carried out through the content analysis of the assessment sheets of the programs offered by CAPES shows that the PPGs, in general, carry out individual actions, taking basic education as an object of research or intervention.
\end{abstract}

\section{Key words:}

Stricto Sensu Graduate Programs, Basic Education, National Graduate Plans.

\section{Introduction}

The Postgraduate Programs (PPG) stricto sensu were institutionalized in Brazil a little over 50 years ago by Opinion no. 977/65 (known as Sucupira Opinion). During this period, the PPG counted on the National Postgraduate Plans (PNPG) guidelines. The current PNPG (2011-2020) contemplates support for basic education as one of the five strategic axes of the stricto sensu postgraduate program, focused on improving the quality of Basic Education, especially in Secondary Education, allowing the involvement of all programs, not being restricted, therefore, to the PPG in education (BRASIL, 2010). This research had as objective to analyze the interfaces of the PPG researched with the basic education. To do so, we selected a PPG from the State University of Campinas (UNICAMP) for each area of knowledge, that is, in the area of "arts", the PPG of Visual Arts; in the area of "biological sciences and health professions", the PPG in Physical Education; in "exact sciences, technology and land", the PPG in Mathematics; and in "human sciences", the PPG in Education.

\section{Results and Discussion}

The research was developed through content analysis (MORAES, 1999) of the assessment sheets of each program made available by the Coordination of Higher Level Personnel (CAPES). To do so, we focus on the section "Interfaces with Basic Education" in the tabs. In this section the programs present the integration actions carried out with Basic Education in the last four years (2013-2016). The data allowed us to list 10 categories regarding the actions undertaken by the PPG, they are: Integrated Program of Initiation to Teaching (PIBID); projects of the Education Observatory; Extension courses; groups of studies; dissertations, theses and publications focusing on basic education; offering discipline focused on basic education; post-graduate students with professional experience in basic education; University of Open Doors (UPA) Program of Unicamp;
Mathematics Olympics activities and Scientific Initiation projects for high school students.

\section{Conclusions}

Finally, it is possible to infer that the actions carried out by the PPG researched are punctual and that there is no continuous and specific action directed exclusively to basic education or in direct articulation with it, ie, the actions are carried out by individual teachers and not as an institutional project of the programs. Moreover, the interfaces, in general, take basic education as an object of research or intervention, but not necessarily as a space of interaction Basic Education and PPG.

\section{Acknowledgement}

To the Student Support Service - Serviço de Apoio ao Estudante (SAE) of UNICAMP, for the concession of the Social Assistance Scholarship - Bolsa Auxílio Social (BAS) to the scientific project that supports this research.

${ }^{1}$ BRASIL. Ministério da Educação. Plano Nacional de Pós-Graduação 2011 2020. Brasília- DF: MEC/CAPES, 2010.

2 MORAES, Roque. Análise de conteúdo. Revista Educação. Porto Alegre, v. 22, n. 37, p. 7-32, 1999. 